\title{
Analysis of Leadership Style, Motivation and Discipline of Employee Performance at Pragaan Public Health Center Sumenep District
}

\author{
Raden Bagus Khairul Anwar', \\ Indasah $^{2}$ \\ ${ }^{1}$ Sumenep District Health Center \\ Pragaan, Indonesia \\ ${ }^{2}$ Master Program of Public \\ Health, Institute of Health Science \\ Strada Indonesia \\ Email: \\ anwarkhairul837@gmail.com
}

Received : October $4^{\text {nd }} 2021$

Accepted : October $15^{\text {rd } 2021}$

Published : November $27^{\text {th }} 2021$

\begin{abstract}
The role of health workers in administering health services is very important, especially as health service implementers, so it is natural that the ability and performance of health workers are one of the determinants of success in health services.. The purpose of this study was to analyze the influence of leadership style, motivation and discipline on employee performance at the public health center Pragaan, Sumenep Regency. The design of this study was an observational quantitative study with a cross sectional approach with the focus of the research being directed at analyzing the influence of leadership style, motivation and discipline on employee performance at public health center Pragaan, Sumenep Regency.with a population of 175 respondents and a sample of 114 respondents who were drawn using the simple random sampling technique. The findings showed that almost half of the respondents had a leadership style in the moderate category as many as 56 respondents $(49.1 \%)$. Almost half of the respondents have medium category motivation as many as 48 respondents $(42.1 \%)$. Nearly half of the respondents have sufficient work discipline as many as 49 respondents (43\%). Nearly half of the respondents have a moderate performance category as many as 51 respondents (44.7\%). Based on the results of the Multiple Linear Regression analysis, it shows that with a p-value of $0.000<0.05$, $\mathrm{H} 0$ is rejected and $\mathrm{H} 1$ is accepted, so it is concluded that simultaneously there is an influence of leadership style, Motivation and work discipline on employee performance at the Pragaan Public Health Center, Sumenep Regency with a magnitude of the influence of $75 \%$. As a leader, the head of the puskesmas can provide appropriate direction, input and supervision to his subordinates so that the performance carried out by health workers can be well organized.
\end{abstract}

Keywords: Leadership style, discipline, performance \& motivation

Copyright (C) 2021 IIK STRADA Indonesia All right reserved.

This is an open-acces article distributed under the terms of the Creative Commons AttributionShareAlike 4.0 International License. 


\section{INTRODUCTION}

Health Development is an effort carried out by all components of the nation which aims to increase awareness, willingness and ability to live a healthy life for everyone so that the highest level of public health can be realized. (Wijaya, 2014). Public health center which is a health service facility that organizes public health efforts and first-level individual health efforts by prioritizing promotive and preventive efforts to achieve the highest public health status in its working area. (Permenkes No. 43 of 2019 concerning public health center).

The following are the results of the achievements of public health services at the Pragaan public health center as of October 2020, namely 60.88\% essential SME (Public Health Efforts). UKM development 44.57\%, Quality 70.2\%, UKP (Individual Health Efforts) $72.2 \%$ and Management $80.1 \%$. The number of civil servant and contract employees is 72 people at the public health Center Pragaan Sumenep. Based on the analysis of the attendance list of 72 people in October 2020, there were 3 people who never filled out the attendance list, 2 people did not fill in the attendance list for 15 times even though they attended work and 8 people did not fill out the attendance list 10 times. while others are often absent on Fridays and Saturdays. There has been a change of the Head of the Puskesmas (Head of the public health Center) every year and has survived 3 times and the public health Center has met the law (Data of the public health Center Pragaan, 2020).

Based on the results of a preliminary study conducted by researchers on October 5, 2020 at the public health center Pragaan, Sumenep Regency to 10 respondents, it was found that a total of 7 respondents $(70 \%)$ had underperformance which was due to the low motivation of health workers to want to work perfectly where this was. This is also due to the ineffective work coordination carried out by the leadership so that the performance of health workers that should be utilized properly becomes less effective. Meanwhile, a number of 3 respondents (30\%) have a good performance because the health worker is a fairly new employee so that they still have a lot of enthusiasm to do their job well.

Performance is a description of the level of achievement of the implementation of an activity / program in realizing the goals, objectives, mission and vision of the organization as stated in the planning strategy of an organization (Mansum, 2015). Widodo (2016) adds that performance is carrying out an activity and perfecting it according to its responsibilities with results as expected. Meanwhile, Anwar (2015) states that performance is the result of work in terms of quality and quantity of a person in carrying out his functions in accordance with the responsibilities given to him.

A leader will play a very important role in the organization. With good leadership, it will increase employee motivation. Leaders must pay attention to the performance of their subordinates and provide a stimulus for performance improvement in the form of giving motivation and rewards to health workers who have high work discipline (Usman, 2016).

Work motivation is related to age, years of service, work performance, recognition, development of individual potential, perception of salary, working conditions, policies and administration, interpersonal relationships and supervision (Bina, 2016). A person's behavior is influenced and stimulated by wants, needs, goals and satisfaction. Stimulation arises from yourself and from outside. These stimuli will create motives and motivations that encourage people to work (Ansory, 2018).

As for the studies that have been made to see the extent to which a person's leadership can affect the performance of health workers or employees. Research by Jumhur Salam (2013) on the Relationship between Leadership Style and Health Worker Performance at public health center Wara Selatan, Palopo City, the results of this study concluded that the leadership style applied by the head of the public health center, based on problem solving, was a participatory leadership style, namely 45 people $(75 \%)$ and the leadership style applied by the head of the public health center based on decision making is the instructional leadership style, namely 30 people (50\%) while the performance of health workers has a good performance category, namely 45 people $(75 \%)$.

Previous research states that leadership is related to work motivation. applied leadership, namely the leader is able to increase passion for work and foster employee behavior. The leader tells what to do, and maintains a sense of security and a pleasant atmosphere (Yulianti, 2013). Other research also states that there is a leadership influence on employee motivation. Motivation is 
very important to improve performance. The influence of leadership on employee work motivation is very relevant to employee performance, because if motivation is not given, employees cannot work productively (Reni, 2015).

Based on the above conditions, the authors are interested in researching the analysis of leadership style, motivation and discipline on employee performance at the Pragaan Health Center, Sumenep Regency.

\section{MATERIALS AND METHODS}

In this study, researchers used a quantitative observational design with a cross sectional approach, namely a study to study the dynamics of the correlation between risk factors and effects, by approaching, observing or collecting data at once (point time approach), that is, each subject. The research was only observed once and measurements were made of the character status or subject variables at the time of examination. This does not mean that all research subjects were observed at the same time (Soekidjo, 2012). This research will analyzeinfluence, leadership style, motivation and discipline on employee performance at the public health Center Pragaan, Sumenep Regency. The total population of 175 respondents and a sample of 114 respondents who were taken using the simple random sampling technique. Data analysis using Linear Regression test. This research has gone through an ethical test number: 2248 / KEPK / I / 2021.

\section{RESULTS}

Table 1 Results of linear regression analysis analysis of leadership style, motivation and discipline on employee performance at the public health center Pragaan, Sumenep Regency which was held on 1-30 March 2021 with a total of 114 respondents

\begin{tabular}{cccccc}
\hline No. & Variable & Sig & B & $R^{2}$ & Sig \\
\hline 1 & Constand & 0.046 & 1,359 & & \\
2 & Leadership Style & 0.000 & 0.265 & 0750 & 0.000 \\
3 & Motivation & 0.011 & 0.263 & & \\
4 & Discipline & 0.036 & 0.204 & & \\
\hline
\end{tabular}

\section{Partial}

a. The influence of leadership style on performance

Based on the results of the Linear Regression analysis, the variable leadership style on performance shows that the p-value is $0.000<0.05$, so $\mathrm{H} 0$ is rejected and $\mathrm{H} 1$ is accepted, so it is concluded that partially there is the influence of leadership style on the performance of employees at public health center Pragaan, Sumenep Regency

b. The effect of work motivation on performance

Based on the results of the Linear Regression analysis, the work motivation variable on performance shows that the p-value is $0.011<0.05$, so $\mathrm{H} 0$ is rejected and $\mathrm{H} 1$ is accepted, so it is concluded that partially there is the influence of work motivation on employee performance at the public health center Pragaan, Sumenep Regency

c. The effect of work discipline on performance

Based on the results of the Linear Regression analysis, the work discipline variable on performance shows that the p-value is $0.036<0.05$, so $\mathrm{H} 0$ is rejected and $\mathrm{H} 1$ is accepted, so it is concluded that partially there is the influence of work discipline on the performance of employees at the public health center Pragaan, Sumenep Regency 


\section{Simultaneously}

Based on the results of the Multiple Linear Regression analysis, it shows that with a p-value of $0.000<0.05, \mathrm{H} 0$ is rejected and $\mathrm{H} 1$ is accepted, so it can be concluded that simultaneously there is influence leadership style, motivation and work discipline on employee performance at the Pragaan Public Health Center, Sumenep Regency with a magnitude of influence of $75 \%$.

\section{DISCUSSION}

\section{A. Leadership Style at the Pragaan Public Health Center, Sumenep Regency}

The results showed that almost half of the respondents had a leadership style in the moderate category as many as 56 respondents (49.1\%). In addition, a number of 31 respondents (27.2\%) have a less category of leadership style. Meanwhile, 27 respondents $(23.7 \%)$ had a good leadership style.

Based on the cross tabulation, it was found that almost half of the male respondents had a leadership style in the moderate category as many as 45 respondents (39.5\%). In addition, a small proportion of respondents aged 36-45 years have a sufficiently categorized leadership style as many as 23 respondents $(20.2 \%)$. Nearly half of the respondents who were coached for $>5$ years had a leadership style in the moderate category as many as 37 respondents (32.5\%). And a small proportion of respondents who have a work position as a nurse have a fairly category leadership style as many as 22 respondents (19.3\%).

An organization automatically has a leader or a leader. A quality leader is a leader who can provide direction to the efforts of all workers in achieving organizational goals. Without leadership or guidance, the relationship between individual goals and organizational goals may become tenuous (weak). This situation creates a situation of individuals working to achieve their own personal goals, while the whole organization becomes inefficient in achieving its goals (Rendra, 2014).

A leader according to Hariyani (2011) is someone who uses his authority and leadership to direct others and is responsible for that person's work in achieving a goal, whereas according to Kartono (2010) a leader is an individual who has skills and strengths, especially skills and strengths in one area so that he is able to influence other people to jointly carry out certain activities for the achievement of one or several goals.

The leadership style plays a very important role in an organization. Experts in the field of organization generally propose a separate definition of leadership. Leaders are defined into individual characteristics, habits, ways of influencing others, interactions, positions in administration, and perceptions of legitimate influence (Kartono, 2010).

The existence of a leader can be seen as a determining factor in organizational life. Even so, it remains to be realized that the central position of the leadership does not mean ignoring the existence of other people, namely subordinates. In leadership there is a relationship between humans, namely the relationship that affects the leadership and the relationship between compliance and obedience from subordinates because it is influenced by the authority of the leader (Timpe, 2012).

Effective leadership will be able to persuade people to stop doing something that is being done, to then do something different according to a common view. Leadership uses change to make progress. Leadership contains everything it takes to stimulate constructive change. Good leadership in an organization plays a very dominant role in the successful implementation of various activities (Timpe, 2012).

According to researchers, a leader in an institution or organization must have the skills, emotional intelligence, assertiveness and so on to condition its members in order to align the 
program plans that must be implemented by an organization. Effective leadership can encourage members so that members will make a minimum of mistakes that are seen or not seen by others. Based on the results of the study, it was found that most of the respondents considered that the leadership style of the head of the public health center Pragaan was good enough so that the current leader was able to coordinate his members well, but there were still some shortcomings that had to be examined again as a leader.

\section{B. Motivation of Employees at Public Health Center Pragaan, Sumenep Regency}

The results showed that almost half of the respondents had a moderate category of motivation as many as 48 respondents (42.1\%). In addition, a number of 44 respondents (38.6\%) have low category motivation. Meanwhile, 22 respondents (19.3\%) have high category motivation.

Based on the cross tabulation, it was found that almost half of the male respondents had low category motivation as many as 41 respondents (36\%). In addition, a small proportion of respondents aged 36-45 years had moderate category motivation as many as 19 respondents (16.7\%). Nearly half of the respondents who were assisted for $>5$ years had a moderate motivation category as many as 33 respondents $(28.9 \%)$. And a small proportion of respondents who have a work position as a midwife have a low category of motivation as many as 22 respondents $(19.3 \%)$.

Work is a form of activity that aims to get satisfaction. This activity involves both physical and mental. Gilmer (2011) argues that work is a human physical and mental process in achieving his goals. Work motivation is an influential condition to generate, lead and maintain behavior related to the work environment (Mangkunegara, 2010).

Various things that become the basis and support for health institutions, are now very much heeded and developed as an effort to professionalism in the midst of cultural development and modernization of the world community. However, the irony for Indonesia is that this still developing country still has a relatively low work productivity due to the many and varied factors that hinder it, generally in the health sector itself. Resource quality and performance still need improvement. Employee productivity becomes the center of attention in its efforts to improve performance which affects the efficiency and effectiveness of the organization. An analysis that concentrates more on performance will place more emphasis on two main factors, namely the motivation of employees and the ability of employees to work (Rosyidah 2014).

The leaders of each public health Center must provide good motivation so as to create conditions in which health workers get inspiration to work hard. Health workers who have high motivation will have an effect on performance. Thus, each public health center can maximize its own resources. If work motivation is not organized and improved, it will become a barrier to achieving organizational goals and have a negative impact on the organization and society at large (Rosyidah 2014).

According to researchers the motivation of an employee in carrying out his responsibilities as an employee of an agency must be high. Because the work done will be given wages every month. However, not all employees have high motivation, because each individual has a different assessment of their work where there are some employees who feel that the work done is too heavy which does not match the wages that will be earned later. Based on the results of the study, it was found that most of the respondents were motivated in the medium category where this category was a general category because it was neither low nor too high. However, there are still some respondents who have work motivation in the low category. 


\section{Discipline of Employees at Public Health Center Pragaan, Sumenep Regency}

The results showed that almost half of the respondents had sufficient discipline category as many as 49 respondents (43\%). In addition, 41 respondents (36\%) had sufficient discipline category. Meanwhile, a total of 24 respondents (21\%) have good discipline category.

Based on the cross tabulation, it was found that almost half of the male respondents had sufficient discipline as many as 39 respondents (34.2\%). In addition, a small proportion of respondents aged 36-45 years have sufficient discipline category as many as 23 respondents (20.2\%). Nearly half of the respondents who were coached for $>5$ years had sufficient discipline category as many as 33 respondents $(28.9 \%)$. And a small proportion of respondents who have a work position as a midwife have sufficient discipline category of work as many as 21 respondents (18.4\%).

Discipline is a condition that causes or encourages employees to act and carry out all activities in accordance with predetermined norms or rules. According to Siagian (2014), discipline is a management action to encourage organizational members to meet the demands of these various conditions. In other words, employee discipline is a form of training that seeks to improve and shape the knowledge, attitudes and behavior of employees so that employees voluntarily try to work cooperatively with other employees and improve their work performance.

Work discipline is a tool used by managers to communicate with employees so that they are willing to change a behavior and as an effort to increase one's awareness and willingness to obey all applicable social rules and norms (Rivai, 2014).

The concept of work discipline according to Sinungan (2010) is: "The mental attitude that is reflected in the actions or behavior of individuals, groups or communities in the form of obedience or obedience to the regulations set by the government regarding ethics, norms and applicable rules. in society for a specific purpose ".

According to Bejo Siswanto (2012), it is actually very difficult to set detailed goals why management needs to develop work discipline. In general, it can be stated that the main purpose of fostering work discipline is for the continuity of the company according to the company's motives.

According to researchers, discipline is something that must be present in an employee who works in any agency, especially government. Discipline is very important because the health worker who is the customer is the patient so that discipline is very important and if something goes wrong it will be very fatal. Based on the results of the study, it was found that most of the respondents had good discipline in the category. However, there are still some respondents who have undiscipline where this is due to many factors, one of which is the role of a leader in an agency. And it can also be caused by the individual factors themselves which do not have a spirit of discipline.

\section{Employee Performance at Public Health Center Pragaan, Sumenep Regency}

The results showed that almost half of the respondents had a sufficient performance category as many as 51 respondents (44.7\%). In addition, a number of 38 respondents (33.3\%) had poor performance categories. While a number of 25 respondents $(22 \%)$ had a good category performance.

Based on the results of the cross tabulation, it was found that almost half of the male respondents had a sufficient performance category as many as 42 respondents (36.8\%). In addition, a small proportion of respondents aged 36-45 years had a sufficient performance category as many as 120 respondents (17.5\%). Nearly half of the respondents who were assisted for> 5 years had a sufficient performance category as many as 32 respondents $(28.1 \%)$. And a small proportion of respondents who have a work position as a midwife have a poor performance category as many as 18 respondents (15.8\%). 
Basically, performance can be seen from two aspects, namely employee performance (individual) and organizational performance. Employee performance is the result of individual work in an organization. While organizational performance is the totality of work achieved by an organization (Handri, 2012).

Performance is a description of the level of achievement of the implementation of an activity / program in realizing the goals, objectives, mission and vision of the organization as stated in the planning strategy of an organization (Mahsun, 2015). Widodo (2016) adds that performance is carrying out an activity and perfecting it according to his responsibilities with results as expected. Meanwhile, Anwar (2015) states that performance is the result of work in terms of quality and quantity of a person in carrying out his functions in accordance with the responsibilities given to him.

Based on the existing theory, it can be concluded that organizational performance is the level of achievement of the implementation of an organization's tasks in an effort to realize the goals, objectives, mission and vision of the organization. It can be seen that the elements contained in organizational performance consist of results or evaluation of job functions, factors that affect employee performance such as motivation, skills, role perceptions, and so on. Achievement of organizational goals and a certain time period (Sasa, 2016).

Keith Davis in the book Anwar (2015) states that the factors that affect performance are the ability factor and the motivation factor. Psychological abilities, consisting of potential abilities (IQ) and reality abilities (knowledge + skills), which means that leaders who have an IQ above average with adequate education for their services and are skilled at doing daily work. Motivation is defined as the attitude of the leader towards the work situation in an organizational environment.

According to researchers, performance is a work result that can be achieved by a person or group of people in an organization according to their respective authorities and responsibilities in an effort to achieve organizational goals legally, does not violate the law, and is in accordance with morals and ethics. Performance is the appearance of the work of personnel both in quality and quantity in an organization. The good performance of an employee will be beneficial for himself in the future. Based on the results of the study, it was found that most of the respondents had a fairly good performance, but there were still some respondents whose performance was low where it was because the work carried out was not in accordance with the target set by the head of the public health center.

E. The Influence of Leadership Style on Employee Performance at the Public Health Caenter Pragaan, Sumenep Regency

Based on the results of the Linear Regression analysis, the variable leadership style on performance shows that the p-value is $0.000<0.05$, so $\mathrm{H} 0$ is rejected and $\mathrm{H} 1$ is accepted, so it is concluded that partially there is the influence of leadership style on the performance of employees at public health center Pragaan, Sumenep Regency

An organization automatically has a leader or a leader. A quality leader is a leader who can provide direction to the efforts of all workers in achieving organizational goals. Without leadership or guidance, the relationship between individual goals and organizational goals may become tenuous (weak). This situation creates a situation of individuals working to achieve their own personal goals, while the whole organization becomes inefficient in achieving its goals (Jijanko, 2013).

Basically, performance can be seen from two aspects, namely employee performance (individual) and organizational performance. Employee performance is the result of individual work in an organization. While organizational performance is the totality of work achieved by an organization (Handri, 2012). 
Performance is a description of the level of achievement of the implementation of an activity / program in realizing the goals, objectives, mission and vision of the organization as stated in the planning strategy of an organization (Mahsun, 2015). Widodo (2016) adds that performance is carrying out an activity and perfecting it according to his responsibilities with results as expected. Meanwhile, Anwar (2015) states that performance is the result of work in terms of quality and quantity of a person in carrying out his functions in accordance with the responsibilities given to him.

Based on the existing theory, it can be concluded that organizational performance is the level of achievement of the implementation of an organization's tasks in an effort to realize the goals, objectives, mission and vision of the organization. It can be seen that the elements contained in organizational performance consist of results or evaluation of job functions, factors that affect employee performance such as motivation, skills, role perceptions, and so on. Achievement of organizational goals and a certain time period (Sasa, 2016).

Keith Davis in the book Anwar (2015) states that the factors that affect performance are the ability factor and the motivation factor. Psychological abilities, consisting of potential abilities (IQ) and reality abilities (knowledge + skills), which means that leaders who have an IQ above average with adequate education for their services and are skilled at doing daily work. Motivation is defined as the attitude of the leader towards the work situation in an organizational environment.

According to Gaspersz (2011) in his book Malcolm Baldrige Criteria For Performance Excellence: Application Examples of Malcolm Baldrige Award Winners, said that a successful performance of a company depends on the leadership that formulates the company's vision, mission and goals and how these are introduced and applied by him in their place of work. The results of the performance of a hospital are good if the hospital's outcome is good. Outcome is the final result of the activities of doctors, nurses and other professional personnel to patients including the number of outpatient and inpatient visits (Nursalam, 2011).

According to researchers, performance is the result or level of success of a person independently during a certain period in carrying out a task compared to various possibilities, such as standard work results, targets or targets and predetermined criteria. Organizational performance can be seen from the existing vision and mission, process performance can be seen from standard operating procedures, and employee performance can be seen from existing work instructions. So that the depiction of the vision and mission of an organization must be able to explain the goals and objectives to be achieved in an organization which are formulated in a main task and function and will become a work unit in creating activities or activities of workers or employees. Thus performance is more oriented towards the work itself in providing results, impacts,. Where this can happen if the coordination, management and leadership at the public health center are well organized, the performance of health workers will also be good. This is because the leader will be seen as functional and the members will carry out according to the leadership's instructions.

F. The Influence of Motivation on Employee Performance at Public Health Center Pragaan, Sumenep Regency

Based on the results of the Linear Regression analysis, the work motivation variable on performance shows that the p-value is $0.011<0.05$, so $\mathrm{H} 0$ is rejected and $\mathrm{H} 1$ is accepted, so it is concluded that partially there is the influence of work motivation on employee performance at the public health center Pragaan, Sumenep Regency

Performance is the result of work that has been carried out by individuals in the organization with the aim of achieving organizational goals. Good individual performance in the organization, of course, will provide good organizational performance as well. Because an 
organization is a series of individuals whose performance is highly dependent on the results of the work of each individual in it. Measurement of employee performance in the company consists of three things, namely quantity, quality, and timeliness (Dhermawan 2012).

Research conducted by Nababan (2012) Factors related to work motivation at the Kuamang Community Health Center show that there is a relationship between work motivation and the performance of good motivated officers will greatly influence employees in improving performance, especially in their work environment and vice versa, if the relationship is not good. with superiors and fellow employees inconvenience will arise which in turn will affect their motivation in carrying out work.

This research is in line with research conducted by Sumarsih (2016) on the influence of work motivation and professional competence on school teacher performance, indicating that high work motivation will result in high teacher performance. In other words, the intrinsic and extrinsic drive that the teacher has to carry out the work will result in the high success of the teacher in meeting the standards for the implementation of the task.

The results of this study were supported by research conducted by Afriana Amelia Nursadin (2012) regarding the relationship between motivation and the performance of midwives at the Sitti Fatimah Regional Hospital, Makassar, said that there was a significant relationship between rewards and midwife performance, most of the respondents were supported by awards good with good performance as many as 25 people $(80.6 \%)$. And a study conducted by Susanto (2011) on the effect of recognition on the performance of health workers in hospitals in the city of Cirebon with a large effect of 58\%. In this study, it was found that there was a relationship between rewards and employee work motivation, rewards had a role in influencing employee work motivation. Awards provide comfort,

According to researchers, motivation is something that causes and supports someone where the individual will be motivated to meet what needs are strongest in him at a certain moment. If it is said that the emergence of a person's behavior at a certain time is determined by a need that has high strength, it is important for each leader to have knowledge of the needs that are felt to be most important to their subordinates. The motivation of an employee, especially in the health sector, will greatly impact the extent to which a person is performing. High motivation can have a good impact on performance to be as expected by the agency. However, if the employee's motivation to work is low, it will result in a decrease in the person's performance. and it can even result in not meeting expectations. So that in accordance with the results of the study, there is an effect of work motivation on employee performance at the public health center Pragaan, Sumenep Regency.

\section{G. The Influence of Discipline on Employee Performance at Public Health Center Pragaan, Sumenep Regency}

Based on the results of the Linear Regression analysis, the work discipline variable on performance shows that the p-value is $0.036<0.05$, so $\mathrm{H} 0$ is rejected and $\mathrm{H} 1$ is accepted, so it is concluded that partially there is the influence of work discipline on the performance of employees at the public health center Pragaan, Sumenep Regency

Employee work discipline is one of the important requirements that must be considered so that organizational goals can be achieved properly. With good work discipline, it means that employees in carrying out their duties must be in accordance with what has been previously determined. Because employees who are disciplined will not neglect their duties and obligations or abuse the authority of their position. The expected work discipline is one that is based on the awareness and responsibility of employees, and is not caused by compulsion or fear. Therefore work discipline needs to be emphasized, especially in government agencies as public servants (Hezza, 2016). 
From a scientific point of view, discipline is essentially an exercise in mind and character with the intention that all actions always obey the rules set out in a social and state organization, and a good measure of discipline, namely how we can measure discipline in general, namely when employees come to the place. work regularly and on time, the quality of work (Yahya, 2017).

Given the importance of employee work discipline in the istandi environment, in its implementation, obeying and obeying all work regulations must be determined in a way that each employee must really exercise discipline by taking into account the provisions given to employees so that it is carried out properly, and disciplinary measures What is good is how we can measure discipline in general, namely if every employee has obedience to working hours, is well dressed at work, uses office equipment properly and carefully, and has the ability to complete the work given properly ( Grendu, 2014).

According to researchers, employee discipline can show how much a sense of responsibility for work where discipline in carrying out tasks is one of the work rules that must be obeyed and obeyed. In carrying out their duties or jobs, an employee must be really consistent with what he does. With a high sense of responsibility for the assigned task, the work performed by employees will be able to run smoothly without a sense of compulsion in carrying out the work, complying with and implementing work regulations is the key to success. With high employee discipline, every worker can see the benefits of this discipline. Therefore, discipline must be instilled in each individual.

H. The Most Dominant Factors in Influencing Employee Performance at the Public Health Center Pranggung, Sumenep Regency

Based on the results of the Linear Regression analysis of each variable, the leadership style on performance shows that the p-value is $0.000<0.05$, so $\mathrm{H} 0$ is rejected and $\mathrm{H} 1$ is accepted, so this variable is the most dominant influence on performance so it is concluded that there is the influence of leadership style on the performance of employees at public health center Pragaan, Sumenep Regency.

Leaders and leadership are the art and skills of a person in using someone to use their power to influence others, in order to carry out certain activities that are directed at predetermined goals. In dealing with various situations and certain conditions, a leader must make efforts to change character. This is because character change is a strategy to solve the problems at hand. Without a strong change in the character of integrity, endurance in facing difficulties and challenges, a clear vision and mission, a person will never become a leader (Thoha, 2013).

Psychologically, a very important aspect of work leadership is the extent to which the leader is able to influence the work motivation of their human resources so that they are able to work productively responsibly on the grounds that employees must be encouraged to work together in the organization, employees must always be encouraged to work and try accordingly. with work demands and employee motivation are very important aspects in maintaining and developing human resources in the organization (Kontesa, 2014).

Improved employee performance will bring progress for the company to survive in a press. aingan unstable business environment. Therefore, efforts to improve employee performance are the most serious management challenges because the success in achieving the goals and survival of the company depends on the quality of the performance of human resources in it. High employee performance is expected by an organization or agency. The more employees who have high performance, the overall productivity of the institution will increase so that the organization or agency will be able to survive in global competition. The role of a leader is important to achieve 
organizational or agency goals, especially with regard to improving employee performance in carrying out their work. Employee performance is a work result that can be achieved by a person or group of people in an organization or agency according to their respective authorities and responsibilities in order to realize organizational goals (Wahab, 2014).

Based on research conducted by Nurmawilis, it shows that to improve employee performance at RSUD Rokan Hulu it is recommended to increase the effectiveness of its leadership style, especially in the aspect of paying attention to new employees, finding employee desires and providing information about the organization and the hospital must also pay more attention to the satisfaction factor. employee work, especially in the aspect of providing promotion policies, awards for the success of tasks and opportunities for growth and self-development (Nurmawilis, 2010).

According to researchers, there is an influence of the leadership style of the head of the health center on the performance of health care workers at the public health center Pragaan, Sumenep Regencycan happen if you can apply three forms of leadership styles. ThreeFurthermore, the transformational leadership style is used when health workers make mistakes while working by gently reprimanding them and when the health worker is working the leader always pays attention to health workers by observing and supervising the work being done. Likewise, the situational style that can be used when making decisions about work problems, health workers who are not optimistic in completing work and when health workers do not work according to predetermined work standards.

\section{CONCLUSION}

1. Nearly half of the respondents have a leadership style in the moderate category as many as 56 respondents $(49.1 \%)$.

2. Nearly half of the respondents have medium category motivation as many as 48 respondents $(42.1 \%)$.

3. Nearly half of the respondents have sufficient work discipline as many as 49 respondents (43\%).

4. Nearly half of the respondents 51 respondents $(44.7 \%)$ had sufficient category performance.

5. There is an influence of leadership style on the performance of employees at public health center Pragaan, Sumenep Regency

6. There is the influence of motivation on the performance of employees at the public health center Pragaan, Sumenep Regency

7. There is the influence of discipline on the performance of employees at the public health center Pragaan, Sumenep Regency

\section{SUGGESTION}

1. For Respondents

It is hoped that as the head of the public health Center it can provide proper direction, input and supervision to their subordinates so that the performance carried out by health workers can be well organized.

2. For Educational Institutions

It is hoped that educational institutions can use the results of this study as input for learning in the influence of leadership style, motivation and discipline on employee performance at the Pragaan public health center in Sumenep Regency and can be developed again for further research to be more useful for readers and for researchers. 
3. For Further Researchers

It is hoped that further research needs to be deepened and added with more specific research analysis of factors that influence employee work discipline at the public health center Pragaan, Sumenep Regency

4. For Puskesmas

It is hoped that the health center can use the results of this study as input for learning to improve leadership style, motivation, discipline and employee performance at the public health center Pragaan, Sumenep Regency.

\section{ACKNOWLEDGMENT}

I state truthfully that to the best of my knowledge, in this thesis manuscript there are no scientific works that have been submitted by other people to obtain an academic degree in a tertiary institution, and there are no works or opinions that have been written or put in order by other people, except those quoted in writing in this text and mentioned in the sources of citations and bibliography. The researcher would like to thank the Head of the Health Office, and all the employees of the Paragaan Community Health Center who were involved in this research.

\section{CONFLICT OF INTEREST}

In this research there is no interest whatsoever related to myself or with other institutions apart from the Strada Indonesia Institute of Health Sciences, Kediri City.

\section{REFERENCES}

Ansori Sudarmanto. (2018). Kinerja dan Pengembangan Kompetensi SDM: Teori, Dimensi Pengukuran, dan Implementasi dalam Organisasi. Yogyakarta: Pustaka Pelajar

Anwar Imam. (2015).Aplikasi Analisis Multivariate Dengan Program. Edisi Ketujuh. Semarang: Badan Penerbit Universitas Diponegoro

Bina Indarto (2016). Kinerja Dan Pengembangan Kompetensi SDM Teori,Dimensi Dan Implementasi Dalam Organisasi, Yogyakarta:Pustaka Pelajar

Handri, (2012). Hanbook Of Leadership. New York: The Free Press

Hariani, Wenny., Dkk. (2011). Engaruh Kompetensi, Pelatihan Dan Motivasi Terhadap Kinerja Karyawan Pt. Pertamina (Persero) Refinery Unit Ii Dumai Jurnal Economica. Vol. 1. No. 1. Hal 115-124

Jijanto (2013).Analisis Fakor Yang Berhubungan Dengan Koordinasi Kerja Pegawai Di Rumah Sakit Jatinegara

Kartono (2016). Pengaruh Budaya Organisasional Dan Lingkungan Kerja Terhadap Kinerja Perawat "Rumah Sakit Mata Dr. Yap" Yogyakarta Dengan Motivasi Dan Kepuasan Keja Sebagai Variabel Pemediasi. Jurnal Ekonomi Dan Bisnis. Vol 2. No 3. Hal 159-174

Mansum Indra. (2015). Analisis Penilaian Kinerja Pegawai Berbasis Kompetensi Di Satuan Polisi Pamong Praja Kabupaten Karawang. Jurnal Manajemen Vol. 10, No. 1. Hal: 1047-1054.

Nursalam. (2013). Metodologi Penelitian Kesehatan. Jakarta : Gramedia

Rendra (2014). Pengaruh Jabatan, Budaya Organisasional, Dan Konflik Peran Terhadap Hubungan Kepuasan Kerja Dengan Komitmen Organisasi: Studi Empiris Di Kantor Akuntan Publik. Jurnal Riset Akuntansi Indonesia. Vol. 5, No. 3. Hal 341- 364

Reni, dkk. (2014). Performance Apprasal Sistem yang tepat Untuk Menilai Kinerja Karyawan dan Meningkatkan Daya Saing Perusahaan, Edisi Kedua. Jakarta: Raja Grafindo Persada.

Rivai, Veithzal dan Sagala, Ella Jauvani. (2014). Manajemen Sumber Daya Manusia untuk Perusahaan dari Teori ke Praktik. Jakarta: Raja Grafindo Persada

Sasa Ike Kusdyah. (2016). Manajemen Sumber Daya Manusia. Yogyakarta:Penerbit Andi,

Timpe and Gearge (2012). Increasing Employee Productivity Job Satisfaction, And Organizational Commitment. Hospital And Health Services Ad. Vol. 41 No. 2. Hal 160- 175.

Widodo Susilo Toto, dkk. (2016). Analisis Pengaruh Gaya Kepemimpinan Terhadap Kepuasan Kerja, Komitmen Organisasi Dan Kinerja Karyawan (Studi Empiris Pada Departemen Agama Kabupaten Kendal Dan Departemen Agama Kota Semarang). Jurnal Studi Manajemen \& Organisasi. Volume 3, Nomor 2. Hal. 69-81. 